\title{
FLIGHT LOADS ACQUISITION FOR PZL-130 ORLIK TCII FULL SCALE FATIGUE TEST
}

\author{
Piotr Reymer \\ Andrzej Leski \\ Air Force Institute of Technology, \\ Warsaw, Poland
}

\begin{abstract}
The following article presents the research conducted under a complex structure integrity program for PZL-130 "Orlik" TC-II trainer aircraft. The aim of the research was to obtain the actual flight loads characteristic for the Polish Air Force which further on will be used to determine characteristic load spectrum for the Full Scale Fatigue Test purpose. This paper presents the methodology as well as a brief discussion of the obtained results.
\end{abstract}

Keywords: Full Scale Fatigue Test, flight loads, strain measurement

\section{INTRODUCTION}

The following article presents the results from flight loads acquisition for PZL-130 "Orlik" Full Scale Fatigue Test. Presented research is part of "SEWST" service life assessment program funded by the Polish Ministry of Defense. This program was necessitated by the fact that the older version TC-I aircraft are going to be converted into TC-II version. This will involve significant structural modifications and development of a modern approach to aircraft maintenance. Hence it is necessary to revise the actual fatigue life estimations for the previous version and to perform detailed structure testing. Part of the program presented in this paper concerns structural integrity and is focused on determination of the actual fatigue life and critical points of the aircraft structure. The aim of the research presented within this paper is to record actual loads exerted on the airplane's structure during regular operation, which will be used to develop a load spectrum for the full scale fatigue test. The research consisted of several main parts which will be presented in detail.

\section{Objectives and assumptions}

Drawing on the experience of the Air Force Institute of Technology it was decided to use a well-known method of strain measurement in order to determining the actual flight loads. The sections and loads to be monitored were suggested by the EADS-PZL "Okęcie".

In order to guarantee high level of the measurements reliability it was decided to increase the number of strain gauges corresponding to a particular load at each location. Such redundancy was also needed since no service was possible during the test flights.

In order to determine the loads exerted on the aircraft structure by means of recorded strain signals, a calibration system was carefully designed and the calibration was scheduled before the planned test flights. Based on the values of forces applied and the strains recorded during calibration, the regression equations were determined. 
The actual flight loads were measured during three stage flight program. Phase I consisted of approximately twenty carefully designed test flights comprising the most common tasks performed during pilot training and display flying. Phase II involved some additional display flights, whereas Phase III (with a reduced number of measured signals) was meant to be an ongoing process of monitored operation.

In addition to the recorded loads, it was necessary to gather coherent signals from the on-board flight recorder, e.g. velocity, pitch/yaw/roll angles etc.

\section{Design of a strain measurement array}

As mentioned in the previous chapter, the flight loads measurement was carried out using strain gauges. The preliminary assumptions concerning the location and loads to be measured were delivered by EADS-PZL "Okęcie". Due to calibration possibilities some changes had to be introduced. Based on those assumptions and available technical documentation a preliminary design of the strain measurement array was obtained.

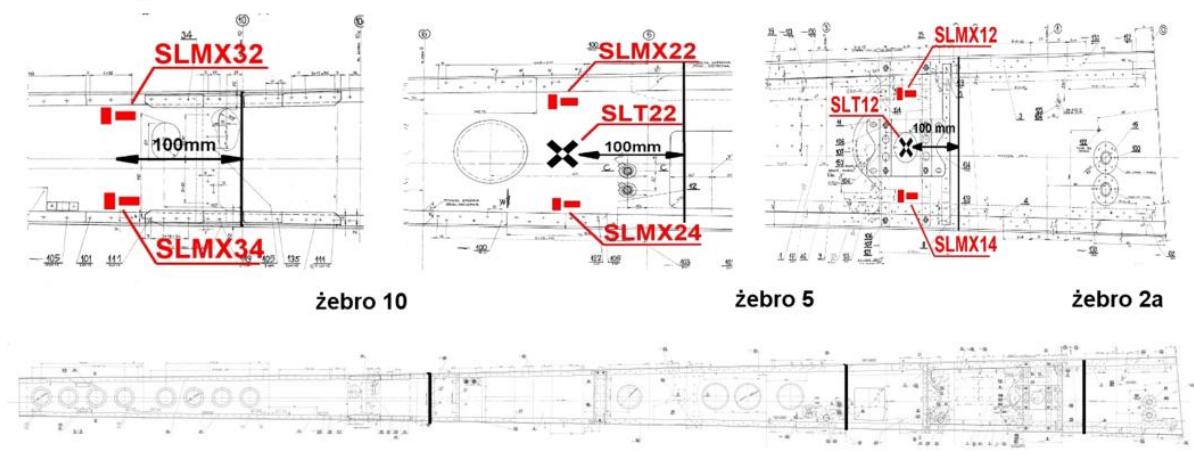

Fig. 1 Example of preliminary strain gauge location. Wing's main spar

The final measurement system consisted of 86 measurement points distributed at 13 different locations. Altogether 27 different loads were measured. The main objective (with level of redundancy up to 8) was to measure the wings bending moments (especially in the root ribs). Moreover, bending moments of the fin, horizontal stabilizer, fuselage (in 2 sections) and landing gear were measured. Furthermore, torque in the root ribs and shear force in two inner sections of the wings were monitored.

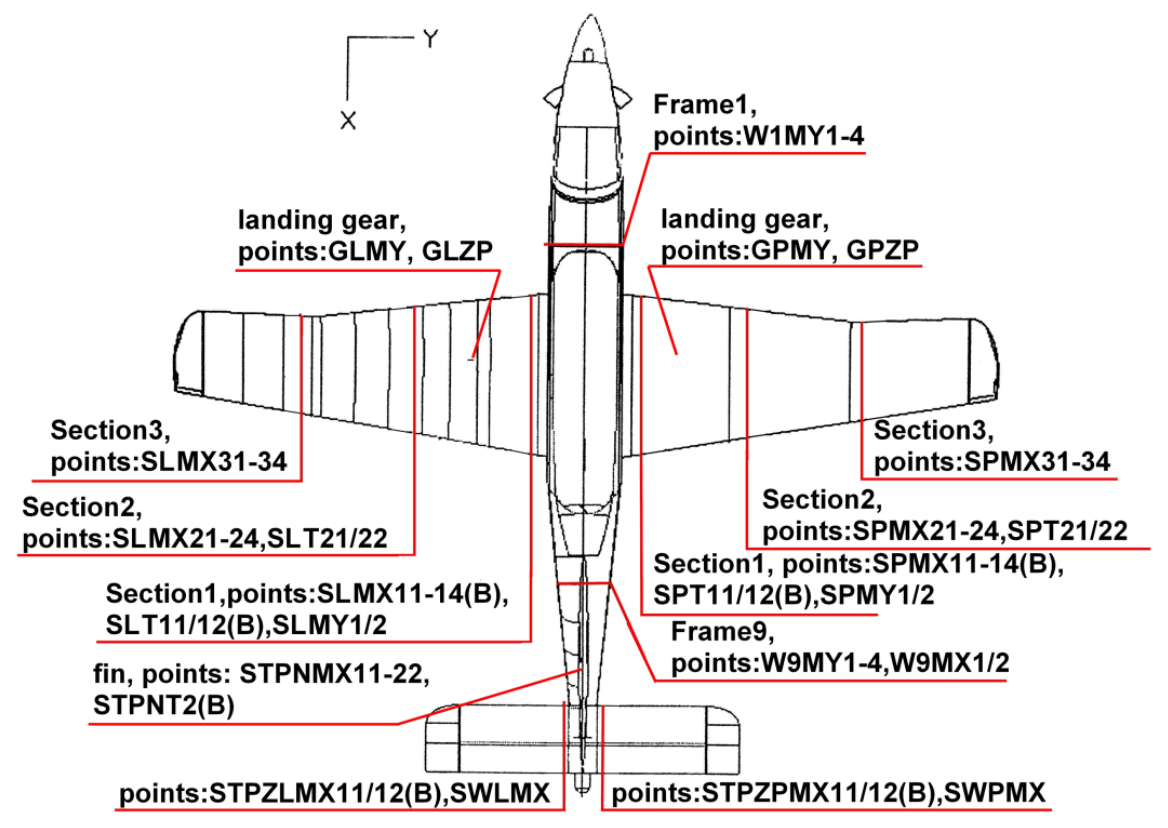

Fig. 2 Sections and installed measurement points 


\section{Strain gauge installation}

In order to realize measurement of the loads assumed it was necessary to use different strain gage configurations. The most common $[\mathrm{NR}]$ are presented below.

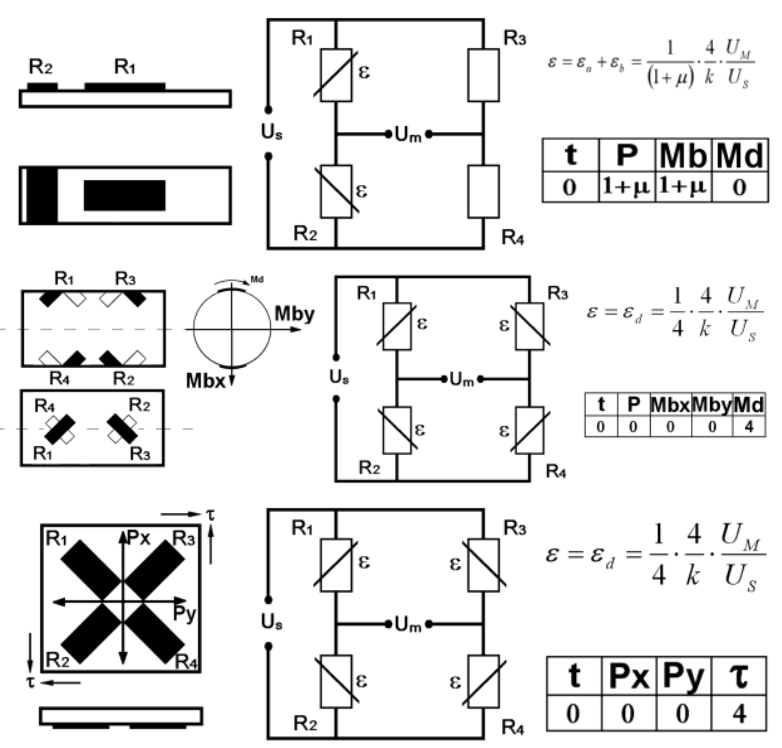

Fig. 3 Strain gauge configurations used for determination of different strain components [1]

Thanks to different configurations it was possible to compensate influence of temperature and eliminate irrelevant strain components. Due to access problems it was not possible to use full bridges for the bending moment and tension measurements but an assumption was made that tension measured in stringers and flanges is caused by global bending moment of the structure.

The final locations of strain gauges were chosen according to the constructors' knowledge of load paths and general load distribution within the structure. Accessibility to the chosen structural elements also played a great role. Thanks to the high level of redundancy it was possible during the analysis of the results obtained to determine which signals are most reliable and must be chosen for loads determination.
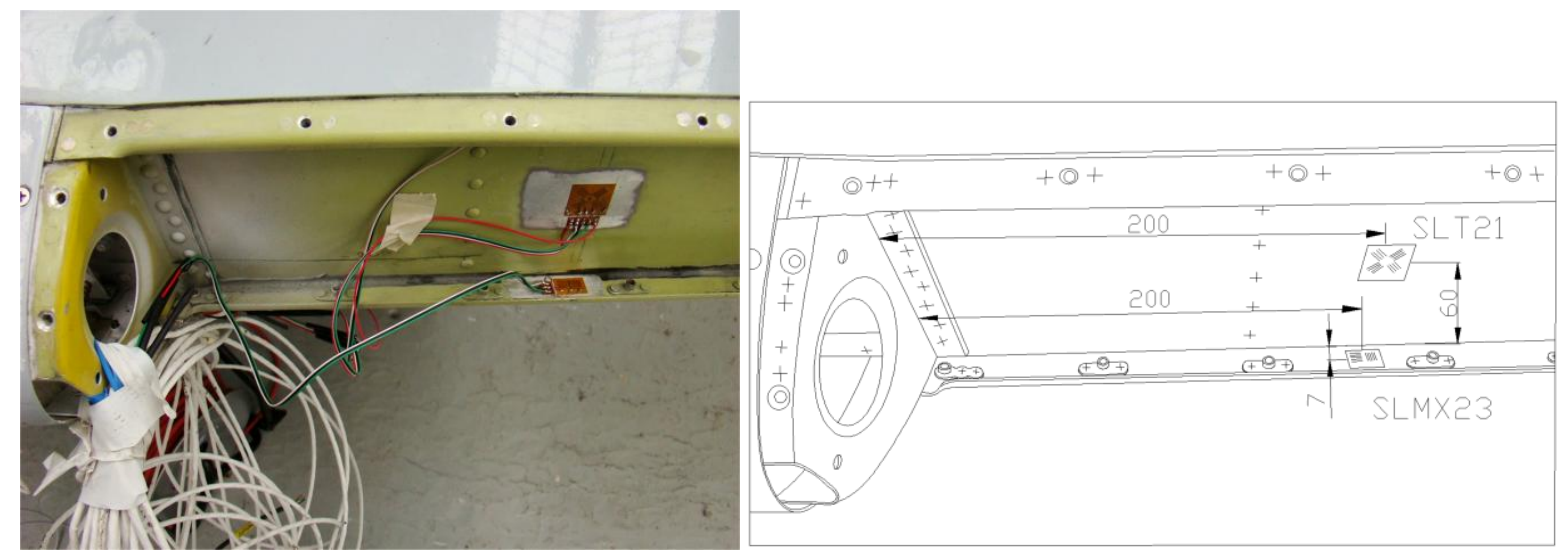

Fig. 4 Strain gauges installed in the middle wing section of the left wing on the front spar. Left part show the actual strain gauges photo and the right one is a part of post installation documentation [4]

\section{Calibration}

The calibration process was carried out in EADS-PZL "Okęcie" according to the detailed procedure described in [5]. The general idea of the process was to exert known loads on the aircraft structure and simultaneously record the strains. The loads were applied by means of jacks and belts while force was constantly monitored with a dynamometer. To enable proper load 
distribution and to prevent any structural damage during the process, a number of special clamps were designed and manufactured.
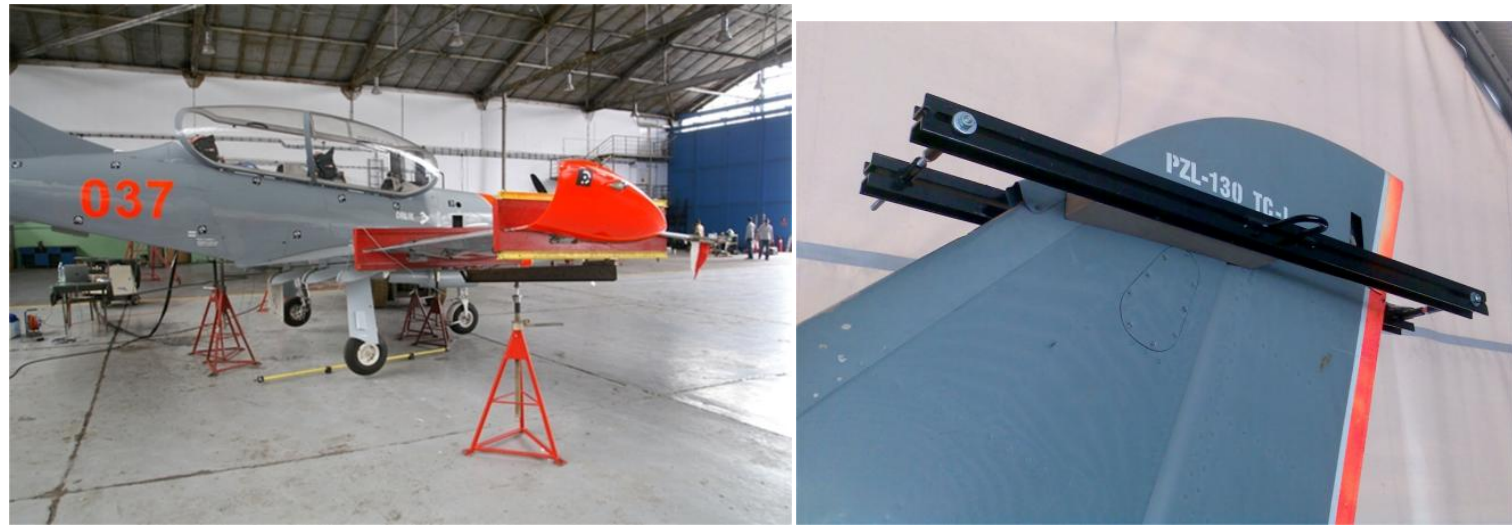

Fig. 5 Wing sensors calibration. Clamps used for wing and fin loading

The level of excitation achieved with the available calibration methods was varying between $30-90 \%$ of operational loads for different loads. Assuming linear behavior of the structure within the whole flight envelope, such a range was sufficient.

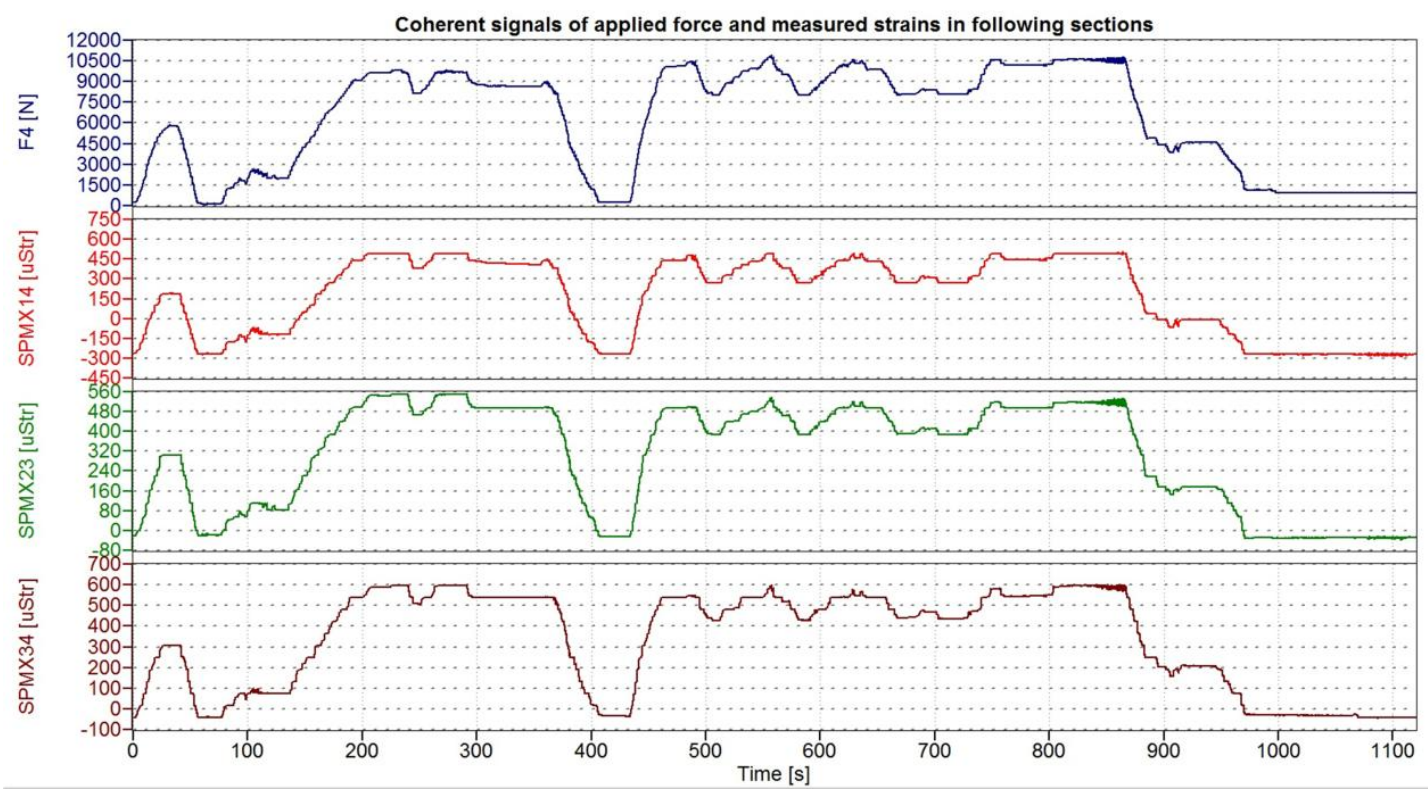

Fig. 6 Applied load and strain signals recorded during wing sensors calibration.Example

The obtained signals were verified in order to check the response of individual strain gauges. At this stage some changes could be introduced. After forwarding the airplane to the Polish Air Force, no changes or additional calibration could be performed, or could be very hard to be carried out.

\section{Determination of the linear regression equations}

The obtained strain signals, after preliminary verification by means of visual inspection, were analyzed using the advanced linear regression module (GRM) in STATISTICA. Since the carried out calibration was a so-called "one point calibration" the developed linear regression equations for each load were based on a single strain signal. The signals were compared and chosen using the least-square method $\left(\mathrm{R}^{2}\right)$ and best set method in order to find the signal of the highest level and correlation with the applied load. 


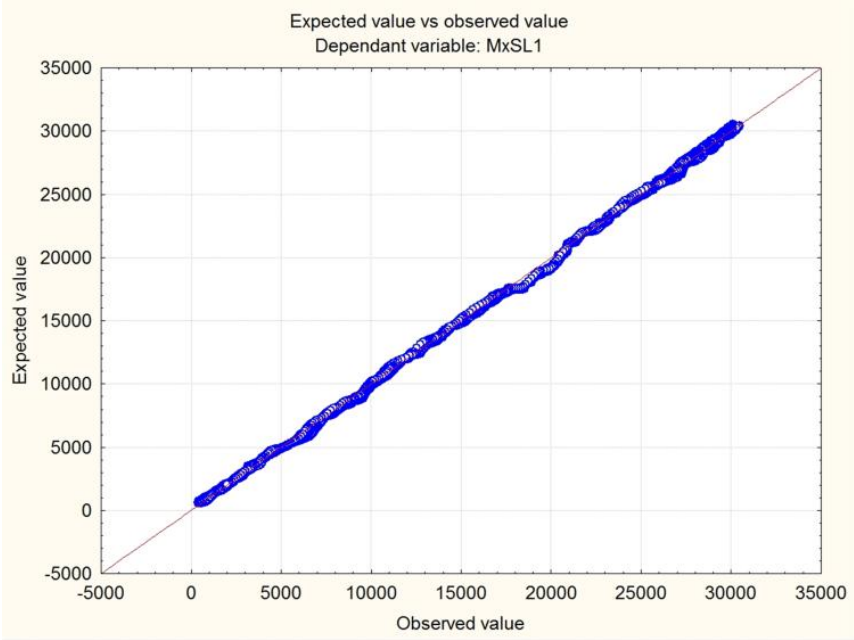

Fig. 7 Calculated value of MxSL1 (bending moment in root rib of the left wing) vs. real value measured with dynamometer

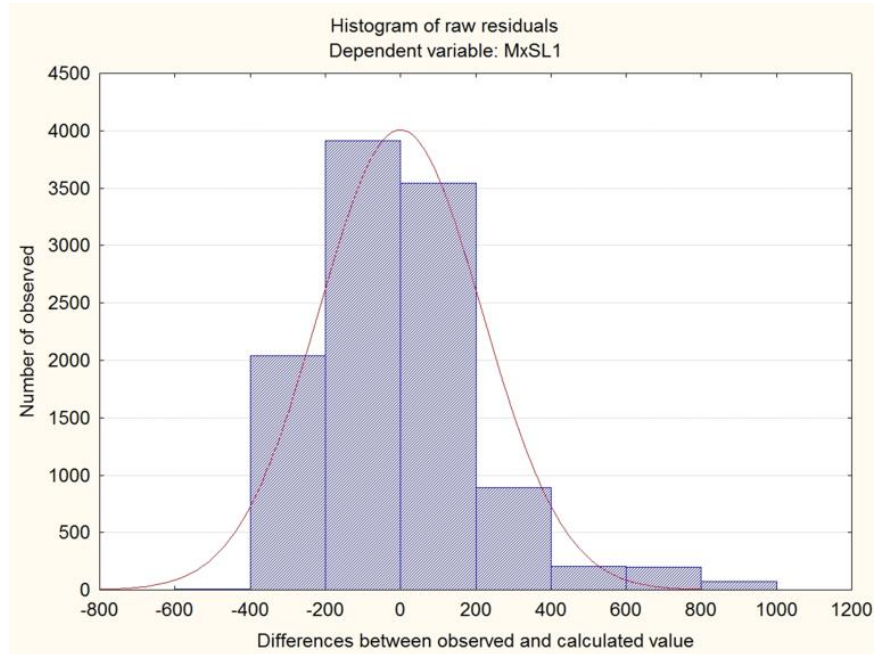

Fig. 8 Histogram of raw residuals

Although only one strain signal was chosen for description of a single load, backup equations were also determined since at this stage it was not certain if the selected strain gauge will work correctly throughout the whole flight test program. The obtained values of $\mathrm{R}$ for the derived equations were always within the range of 0,9-0,999.

\section{Test flights}

In order to determine the values of actual loads acting on the aircraft structure during flight it was necessary to perform a series of specially designed test flights. Test flights were divided into three phases.

Phase I was a series of carefully designed flights comprising the most common tasks performed during the pilot training. The flights were scheduled using statistical approach [6]. Those flights are presented in table 1 and denoted with letter A.

Phase II was a series of autonomous flights without any restrictions. The recording started and ended automatically without the pilot's interference and each flight was recorded in a separate file. Since the EADS-PZL "Okęcie" was taking part in the contest for a trainer aircraft for the Indian Air Force, the flights recorded within phase II are mostly high maneuver display flights. Due to reasons beyond the Air Force Institute of Technology, Phase II comprised only 4 flights. Those flights are represented in Table 1 and denoted with letter B. 
Table 1 Summary of flight test program

\begin{tabular}{|c|c|c|c|c|}
\hline Flight number & Description & $\begin{array}{c}\text { Time of } \\
\text { flight }\end{array}$ & $\begin{array}{c}\text { Number of } \\
\text { landings }\end{array}$ & $\begin{array}{c}\text { Number of } \\
\text { spins }\end{array}$ \\
\hline 2A & Transfer flight & $65[\mathrm{~min}]$ & 1 & 0 \\
\hline 3A & Preliminary test flight & $65[\mathrm{~min}]$ & 1 & 12 \\
\hline 4A & Preliminary test flight & $65[\mathrm{~min}]$ & 1 & 12 \\
\hline 5A & Landings & $87[\mathrm{~min}]$ & 10 & 0 \\
\hline 6A & Landings & $87[\mathrm{~min}]$ & 10 & 0 \\
\hline 7A & Simple maneuvers & $90[\mathrm{~min}]$ & 2 & 0 \\
\hline 8A & Simple maneuvers & $91[\mathrm{~min}]$ & 2 & 0 \\
\hline 9A & Stalling and spins & $73[\mathrm{~min}]$ & 1 & 4 \\
\hline 10A & Stalling and spins & $71[\mathrm{~min}]$ & 1 & 4 \\
\hline 11A & Intermediate maneuvers & $68[\mathrm{~min}]$ & 1 & 0 \\
\hline 12A & Intermediate maneuvers & $75[\mathrm{~min}]$ & 1 & 0 \\
\hline 13A & Flight through clouds & $47[\mathrm{~min}]$ & 2 & 0 \\
\hline 14A & Flight through clouds & $45[\mathrm{~min}]$ & 1 & 0 \\
\hline 15A & Advanced maneuvers & $70[\mathrm{~min}]$ & 1 & 0 \\
\hline 16A & Advenced maneuvers & $73[\mathrm{~min}]$ & 1 & 0 \\
\hline 1B & Display flying & $27[\mathrm{~min}]$ & 1 & 0 \\
\hline 2B & Display flying & $17[\mathrm{~min}]$ & 1 & 0 \\
\hline 4B & Display flying & $13[\mathrm{~min}]$ & 1 & 0 \\
\hline 5B & Display flying & $16[\mathrm{~min}]$ & 1 & 0 \\
\hline
\end{tabular}

Phase III was designed as an ongoing process to be continued until the tested airplane is withdrawn from operation. In this phase, only 8 strain measuring points were left ( 2 in each wing, one in the fin and the left part of the horizontal stabilizer and the final two in the rear fuselage section).

\section{Determination of flight loads}

After the completion of Phase III, the obtained test results were analyzed for any data loss or strain gauge malfunction. The raw data obtained from flights had to be post processed. Firstly, the signals had to be verified and modified in case the start value was different from zero. Secondly, the values of loads were calculated with the use of the determined regression equations. Since it was decided that the zero values will be set on-ground, the offset values of actual loads had to be taken into account.

Very few strain gauges had to be neglected, mostly due to the high level of redundancy. Hence it was possible to compare the loads measured in the symmetrically positioned sections in order to check loads magnitudes in symmetric maneuvers and define difference in other cases. Laborious data testing was performed in order to verify that the regression equations obtained from calibration were true for the whole load range in flight tests (e.g. in test flights the $\mathrm{Nz}$ factor was in the range $-1,5-5,3$, while during calibration the value of up to 1 was possible to be achieved). Nevertheless, when compared, the obtained loads and the loads defined by the constructor for different values of $\mathrm{Nz}$ were similar and no further changes had to be introduced. 


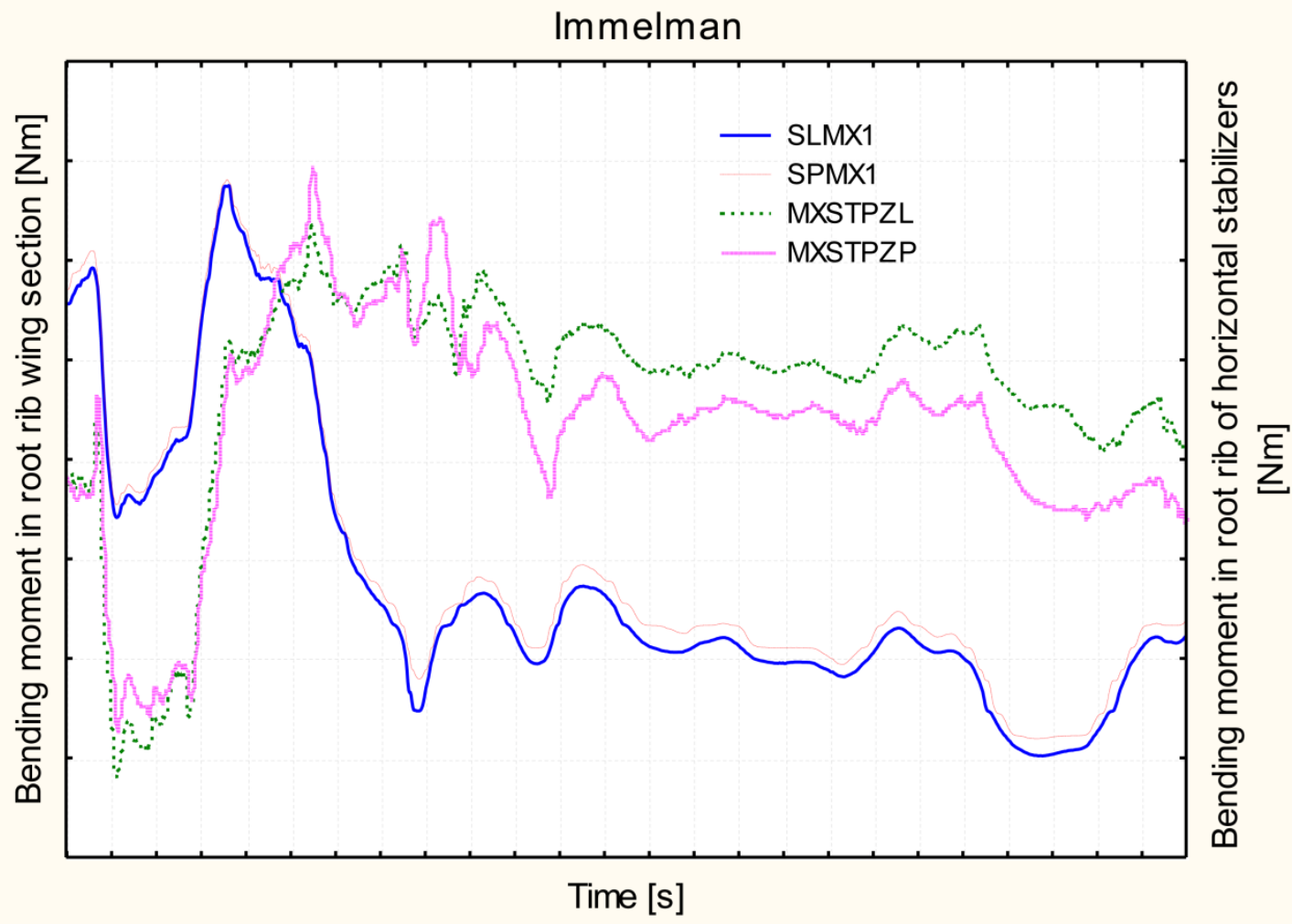

Fig. 9 Example results. Bending moments in root ribs of wings and horizontal stabilizers during immelman maneuver

\section{Conclusions}

The obtained load history will be the basis for determination of load spectrum for the Full Scale Fatigue Test. The prepared block will represent 200 flight hours. Since the sampling frequency during test flight was set to $100 \mathrm{~Hz}$ (and $400 \mathrm{~Hz}$ for buffeting), the load spectrum requirements from VZLU extort data filtering in order to decrease the number of load lines in the block. Another method for decreasing load lines consists in the determination of peak load values and neglecting those in between. The determined load spectrum block will be tested on the prepared test specimen in order to verify the load ranges and sequences.

\section{REFERENCES}

[1] Kottkamp, E., Wilhelm, H., Kohl, D. (1976). Strain gauge measurements on aircraft, NATO Advisory Group for Aerospace Research and Development, AGARDograph No. 160 Vol.7, April.

[2] Jenkins, J.M. \& DeAngelis, V.M. (1997). A summary of numerous strain-gage load calibrations on aircraft wings and tails in a technology format, Nasa Technical memorandum 4804. Edwards, California: Dryden Flight Research Center.

[3] Skopinski, T.H., Aiken, W.S., Jr. \& Huston W.B. (1954). Calibration of strain-gage installations in aircraft structures for the measurement of flight loads. The National Advisory Committee for Aeronautics. (report No. 1178)

[4] Opracowanie koncepcji pomiaru obciażeń samolotu PZL-130 Orlik TC-II. Warszawa: Instytut Techniczny Wojsk Lotniczych. (Sprawozdanie Nr 57/31/2010)

[5] Dokumentacja techniczna z zabudowy czujników tensometrycznych na płatowcu PZL-130 Orlik TC-II $n r$ boczny 037. Warszawa: Instytut techniczny Wojsk Lotniczych. (Sprawozdanie Nr 89/31/2010) 
[6] Skalowanie czujników tensometrycznych zamontowanych na samolocie PZL-130TC-II Orlik nr kadtubowy 037. Warszawa: Instytut Techniczny Wojsk Lotniczych. (Sprawozdanie Nr 127/31/2010)

[7] Analiza programów szkolenia lotniczego realizowanych na samolocie PZL-130 Orlik pod katem obciqzienie struktury samolotu, Warszawa: Instytut Techniczny Wojsk Lotniczych. (Sprawozdanie Nr 134/31/2010)

[8] Report from competition of flight tests for loads measurement in PZL-130 "Orlik" TCII structure with KAM-500 system. Air Force Institute of Technology. Warsaw, Poland. (No. 4/36/2010)

[9] Wyznaczanie równań aproksymujacych do obliczania sit wewnętrznych $w$ strukturze samolotu PZL-130 "Orlik" TC-II na podstawie pomiaru tensometrycznego. Warszawa: Instytut Techniczny Wojsk Lotniczych. (Sprawozdanie Nr 164/31/2010) 